\title{
Regulation of Endoplasmic Reticulum Stress Response by the Immobilization Stress
}

\author{
Kisang Kwon ${ }^{{ }^{\dagger}}$, Young-Sook Kwon ${ }^{{ }^{\dagger}}$, Seung-Whan $\mathrm{Kim}^{2}$, Dong-Woon Kim ${ }^{1}$ and O-Yu Kwon ${ }^{1}$ * \\ ${ }^{1}$ Departments of Anatomy, School of Medicine, Chungnam National University, Tagon 301-747, Korea \\ ${ }^{2}$ Department of Emergency Medicine, Chungnam National University Hospital, Taejon 301-721, Korea \\ ${ }^{3}$ Department of Nursing, Joongbu University, Chungnam 312-702, Korea
}

Received July 3, 2012 /Revised July 11, 2012 /Accepted August 8, 2012

\begin{abstract}
Many kind of cell stresses induce gene expression of unfolded protein response (UPR)-associated factors. This study demonstrated that up- and down-regulation of gene expression of endoplasmic reticulum (ER) stress chaperones and ER stress sensors was induced by immobilization stress in the rat organs (adrenal gland, liver, lung, muscle). However, no statistically significant regulation was detected in the others (heart, spleen, thymus, kidney, testis). The results are the first to show that immobilization stress induces UPR associated gene expression, will help to explain immobilization stress-associated ER stress.
\end{abstract}

Key words : Immobilization stress, endoplasmic reticulum (ER) stress, ER chaperone, ER stress sensor

\section{서 론}

조직을 이루고 있는 각각의 세포는 외부의 급격한 환경변화 에 적응하여 정상적인 생리 상태를 유지하기 위한 세포내 자 체 조절능력을 가지고 있다. 세포의 정상적인 생리 상태를 교 란시키는 것을 총칭하여 세포스트레스(cell stress)라고 한다. 특히, 세포소기관인 소포체(endoplasmic reticulum, ER)에 크 게 영향을 미치는 세포스트레스를 소포체스트레스(ER stress) 라고 한다[8]. 분비단백질은 ER내에서 posttranslational modification을 거쳐 정상적으로 세포외로 분비되어야 하지만 다 양한 ER stress에 의해서 소포체내강(ER lumen)에 축적된다. 변이단백질의 발현과 비정상적인 환경, 정상 분비단백질의 과 잉생산이 대표적인 원인으로 생각할 수 있다. 이 같은 ER stress에 세포가 대응하는 가장 기본적인 응답을 소포체스트 레스응답(unfolded protein response, UPR)로 총칭하며 특정 단백질의 전사유도와 세포의 총 단백질 번역을 억제하는 system이다[2]. 이때에 ER lumen에서 UPR에 관여하는 단백질들 을 소포체샤페론(ER chaperone)이라고 하다. 이들은 ER lumen에서 정상적으로 단백 질이 folding \& assembly할 수 있는 환경을 제공해주는 일에 중추적인 역할을 한다. 즉, ER chaperone은 새롭게 합성된 폴리펩다이드의 folding, 단백질의 세 포내 이동 혹은 세포외 분비, 비정상적인 구조를 가진 단백질 의 분해 등, 단백질이 처음 만들어져서 성숙하여 분비 및 분해 될 때까지의 전 과정에 걸쳐서 관여하는 단백질이다. 이처럼

*Corresponding author

Tel : +82-42-580-8206, Fax : +82-42-586-4800

E-mail : oykwon@cnu.ac.kr

† These authors contributed equally to this work.
ER chaperone은 세포내의 여러 가지 단백질이 정상적인 기능 을 가질 수 있도록 종합적인 품질관리기능을 수행하고 있다 (ER quality control, ERQC) [9]. ERQC기능에 의해서 불량한 분비단백질이 과도하게 ER lumen에 축적되면 질병으로 나타 나는데 이를 포괄적으로 ER storage disease (ERSD)라고하며, congenital hypothyroidism, albinism tyrosinase deficiency, polyglutamine diseases와 같은 질환이 알려져 있다[3]. ER stress는 다양한 inducer에 의해서 유도된다. 대표적인 것으로 는 tunicamycin 처리에 의해서 당단백질의 glycosylation이 방 해 받았을 때, A23187 혹은 thapsigagin에 의해서 ER lumen의 $\mathrm{Ca}^{2+}$ depletion이 일어날 때, ER lumen에 과도한 malfolded 단백질이 축적될 때, DTT와 같은 환원제에 의해서 단백질의 3 차구조에 이상이 생길 때, virus 감염 혹은 cancer와 같은 병 리적인 상태가 될 때이다. 이때에 관여하는 ER signal pathway에 직접 작용하는 3종류의 ER stress sensor (IRE1, PERK, ATF6)가 알려져 있다[11]. 세포가 ER stress를 받으면 ER lumen에서 BiP과 결합하고 있는 IRE1이 monomer에서 인산화 된 dimer가 되어, 세포질의 XBP-1 mRNA의 splicing이 일어 나 XBP-1단백질이 생산되어 chaperone 생합성을 촉진한다. PERK 역시 인산화된 dimer가 되면서 핵전사인자인 eIF2a의 인산화를 유도하여 세포 전체의 단백질합성을 저해함으로써 세포들 보호한다. 그리고 ATF6은 ER stress를 받으면 세포질 쪽의 단편이 떨어져 나와서 ERSE (ER stress element)와 결합 한다. 이같이 세포는 ER stress를 받을 경우에 자신을 보호할 수 있는 기전을 가지고 있다. 이처럼 다양한 자극에 의해서 ER stress가 유도되어 세포가 적응을하는것이 알려져있다[10]. 설치류를 포함하는 동물은 자가 방어기전의 하나로 타 동물 로 부터 멀리 도망가려는 습성을 가지고 있다. 실험적으로도 설치류를 작은 상자에 가두면 스트레스를 받아서 신경발생이 
저해되어 우울증(depression)과 같은 현상을 보이지만, 항우 울제(antidepressants)를 투여하면 반대효과가 나타난다. 이처 럼 동물을 움직이지 못하게 하는 스트레스를 부동스트레스 (immobilization stress)라고 한다. 지금까지 알려진 대표적인 부동스트레스 관련연구는 다음과 같다. 부동스트레스는 catacholamine의 생합성 조절, peroxiredoxin I \& II의 발현 조절, leptin signaling 조절, acetylcholinesterase 활성조절, 지방-단 백질-DNA의 oxidative damage 원인에 깊이 관여한다[1,4-7]. 그러나 아직까지 부동스트레스에 의한 ER stress유도에 관련 된 보고는 없다. 본 연구는 처음으로 부동스트레스가 세포생 존에 중요한 기전중의 하나인 ER chaperone 및 ER signaling 의 발현을 조절하는지를 알아보았다.

\section{재료 및 방법}

실험동물인 Sprague Dawley계 흰쥐(수컷, 4 주령)는 다물 사이언스(대전시)에서 구입하여 사용하였다. 각각 3마리씩 대 조군과 부동스트레스를 가한 군으로 나누어 실험하였다. 부동 스트레스 방법은 Kvetnansky \& Mikulaj 실험방법을 사용하 였다[4]. 할로탄을 사용하여 가볍게 흡입마취 시킨 후 평평한 아클릴 판에 흰쥐의 네발에 시판하는 청테이프를 이용하여 등이 아래를 향하도록 하여 움직이지 못하게 붙였다. 그리고 난 후 6시간동안 방치하여 부동스트레스를 주었다.

조직으로부터 total RNA을 얻기 위하여 cold $\mathrm{PBS}$ 로 충분히 세정한 다음에 사용한다. $1.5 \mathrm{ml}$ tube에 RNA isolation reagent (TRI-REAGENT)를 $500 \mu 1$ 와 잘게 절단된 조직을 넣고 초음파분쇄기로 2-3분 동안 충격을 준다. 여기에 $100 \mu \mathrm{l}$ 의 chloroform을 첨가하여 충분히 섞어준 다음 $13,000 \mathrm{rpm}, 4^{\circ} \mathrm{C}$ 에서 15 분 동안 원심 분리하였다. 약 $500 \mu \mathrm{ll}$ 의 상등액을 취하여 새로운 tube로 옮기고 동량의 isopropanol 넣고 상온에서 10 분 정도 처리한 후 $13,000 \mathrm{rpm}$ 으로 10 분 동안 원심분리하고 tube의 바닥에 얻어진 pellet에 $75 \%$ ethanol을 초기 RNA isolation reagent 양과 동일한 $500 \mathrm{\mu l}$ 넣고 $12,000 \mathrm{rpm}$ 으로 5 분 동안 원심 분리하여 최종적으로 total RNA를 얻었다. DEPC가 처리된 증류수에 녹여 UV spectrophotometer로 정량하였다. RT-PCR (reverse transcription polymerase chain reaction)은 RNA $(3 \mu \mathrm{g})$ 를 $80^{\circ} \mathrm{C}$ 에서 3 분 가열하여 denaturation 시킨 후 바로 얼음에 담가둔다. $10 x$ buffer $3 \mu \mathrm{l}$ dNTP $4 \mu \mathrm{l}, 1 \mu \mathrm{l}$ 의 oligo-dT (300 ng), 10,000 U의 역전사효소와 RNase inhibitor 를 첨가하고 총 $30 \mu 1$ 가 되게 한 후 $42^{\circ} \mathrm{C}$ 에서 1 시간 30 분 간 반응시켜 $\mathrm{cDNA}$ 를 합성한다. 반응이 끝난 후 $94^{\circ} \mathrm{C}$ 에서 2 분 반응시켜 역전사효소를 inactivation시킨 다음 최종 $100 \mu 1$ 로 맞춘다. 그 다음 단계로 $\mathrm{cDNA}$ 를 증폭하기 위해서 $\mathrm{PCR}$ 을 수 행하였다. PCR 반응액 $20 \mu 1$ 에 각각의 forward 와 reverse pri$\mathrm{mer}$ 를 넣어서 $94^{\circ} \mathrm{C} 5$ 분, $94^{\circ} \mathrm{C} 30$ 분, $57^{\circ} \mathrm{C} 40$ 초, $72^{\circ} \mathrm{C} 40$ 초로 27회 반복하여 전기영동으로 확인하였다. 사용된 forward 와 reverse primer는 아래와 같다. F (5'-AGTGGTGGCCACT AATGGAG-3') and R (5'-TCTTTTGTCAGGGGTCGTTC-3') for Bip; F (5'-TGTGGATGGCACGGTAGAAG-3') and R (5'-GGTGCCCAGGTTTTTAACCA-3') for GRp94; F (5'GCATCATGCCATCTCTGCTA-3') and R (5'-GGCATCTTC ATCCCAGTCAT-3') for CNAX; F (5'-GGACTGGGACGAA GAGATGG-3') and R (5'-CCTCTGCTCCTCATCCTGCT-3') for Calr; F (5'-AAACTCCTCCCAGCGTTTCA-3') and R (5'-TAGGCCTCCAAGGACTGGAA-3') for EDEM; F (5'-CA GAGTTCTGCCACCGCTTC-3'), and R (5'-TCCTCGAGATC GTCATCATC- $\left.3^{\prime}\right)$ for PDI; F (5'-AGTGGTGGCCACTAAT GGAG-3') and R (5'-TCTTTTGTCAGGGGTCGTTC-3') for ERp29; F (5'-TGATTGGACACCTCCACCTG-3'), and R (5'-GGTCACCGACTCCCTGAAAG-3') for ERp72; F (5'-TGT GCTGTCAAACCCTGCCATT-3') and R (5'-ATTGATGCTT GCGTGTAGGCCA-3') for Ero1; F (5'-CTAGGCCTGGAGG CCAGGTT-3') and R (5'-ACCCTGGAGTATGCGGGTTT-3') for ATF6; F (5'-CAGAGTTCTGCCACCGCTTC-3'), and R (5'-TCCTCGAGATCGTCATCATC-3') for PDI; and R (5'-CC ACCCTGGACGGAAGTTTG-3') for IRE1; F (5'-GGTCTG GTTCCTTGGTTTCA-3') and R (5'-TTCGCTGGCTGTGTA ACTTG-3') for PERK; F(5'-TGAGTCTCTGCCTTTCGCCTTT$\left.3^{\prime}\right)$, and R ( $5^{\prime}$-TCAGCAAGCTGTGCCACTTT-3') for Chop; F (5'-CGTTCAGACAGAGGCCAGTTC- $\left.{ }^{\prime}\right)$, and R (5'-CGA GGACCACCATCATCC-3') for Rpn1; F (5'-AGCCATGTAC GTAGCCATCC-3') and R (5'-CTCTCAGCTGTGGTGGTG AA-3') for $\beta$-actin

Western blotting 은 Protein electrophoresis kit (ATTO Co., Japan)를 사용하여 $12 \% \mathrm{SDS}-\mathrm{PAGE}$ 에 준비된 sample을 전기 영동 하였다. 전기영동이 끝난 후 transfer kit (Bio-RAD)를 사용하여 gel의 protein을 PVDF cell membrane에 transfer buffer (20 mM Tris-HCl, $150 \mathrm{mM}$ glycine, 20\% methanol, $\mathrm{pH}$ 8.3)를 사용하여 transfer하였다. Transfer가 끝난 후 membrane을 3.75\% skim milk in PBST (PBS, 0.05\% Tween 20)를 사용하여 상온에서 1 시간 동안 blocking하였다. Blocking이 끝 난 후 1차 항체를 반응 시킬 때에는 5\% skim milk in PBST에 $1: 1,000$ 의 비율로 희석하여 $4^{\circ} \mathrm{C}$ 에서 2 시간 동안 반응시켰다. 1 차 항체 반응이 끝난 후 membrane을 PBST를 10 분씩 5 회 상온에서 shaker를 사용하여 세척하였다. 세척이 끝난 후 2차 항체를 반응 시킬 때에는 PBST에 1:2,000의 비율로 희석하여 상온에서 1 시간 동안 반응 시켰으며, 반응이 끝난 후 membrane을 PBST를 10분씩 5회 상온에서 shaker를 사용하여 세 척하였다. 세척이 끝난 후 West save (Lab Frontier, Korea)을 사용하여 발색반응을 유도한 후 X-ray film에 감광하여 결과 를 분석하였다. 


\section{결과 및 고찰}

부동스트레스를 받은 rat를 희생시켜서 RT-PCR을 하기 위 한 total RNA와 SDS-PAGE를 하기 위한 단백질을 각각 조직 (heart, spleen, thymus, kidney, testis, adrenal gland, liver, lung, muscle)에서 분리하였다. 부동스트레스가 각 장기에서 ER chaperones과 ER signaling 관련 유전자들의 발현조절에
관여하는지를 알기 위하여 RT-PCR로 그들의 발현을 알아보 았다. Bip (immunoglobulin heavy chain-binding protein)과 GRp94 (glucose regulated protein $94 \mathrm{kDa}$ )는 ER lumen에서 미숙 혹은 불완전한 단백질의 folding \& assembly를 돕는 general chaperones, calnexin과 calreticulin은 ER lumen에서 당단백질의 folding \& assembly를 돕는 lectin chaperones, ER-associated glycoprotein degradation에 관여하는 EDEM
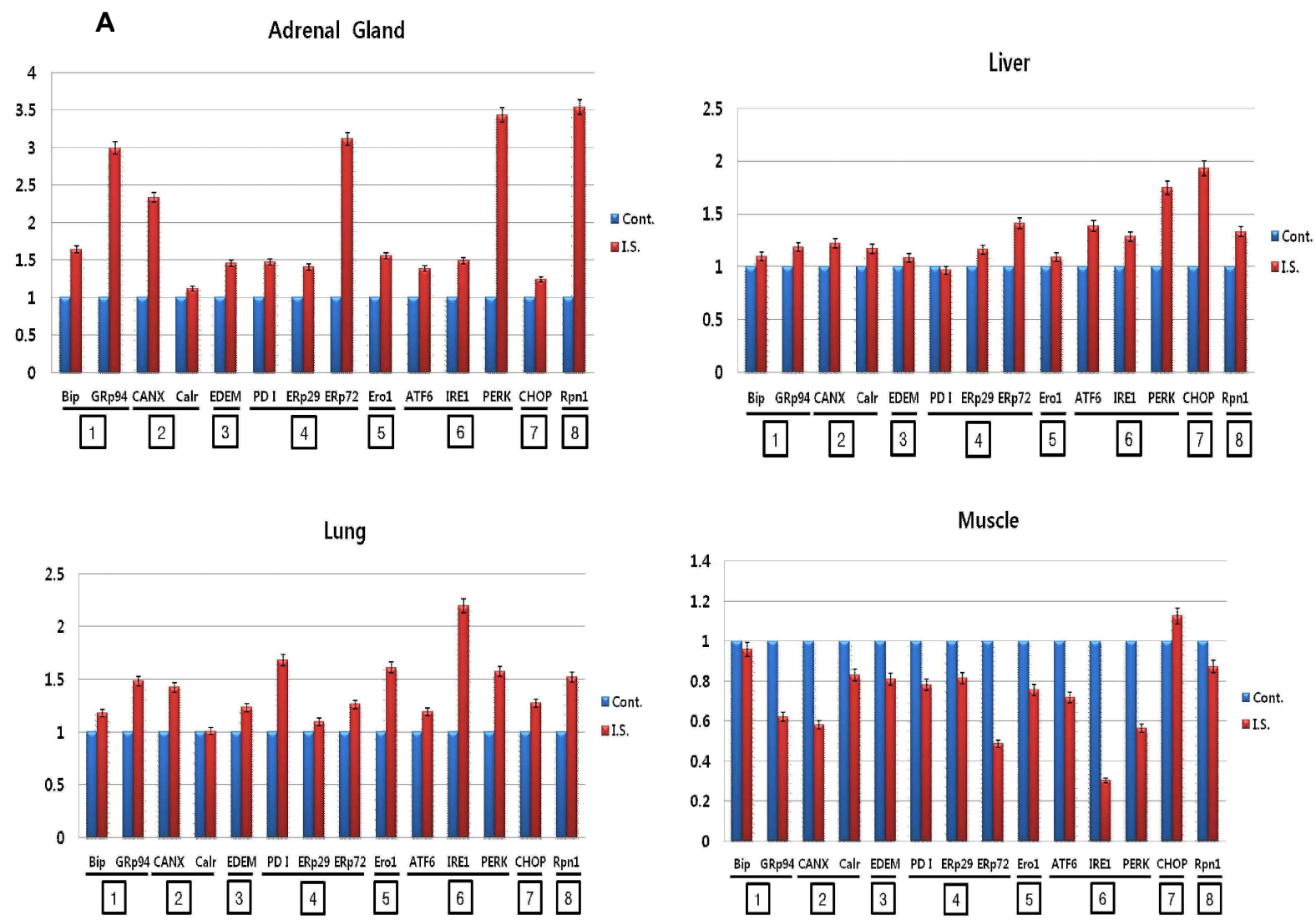

B

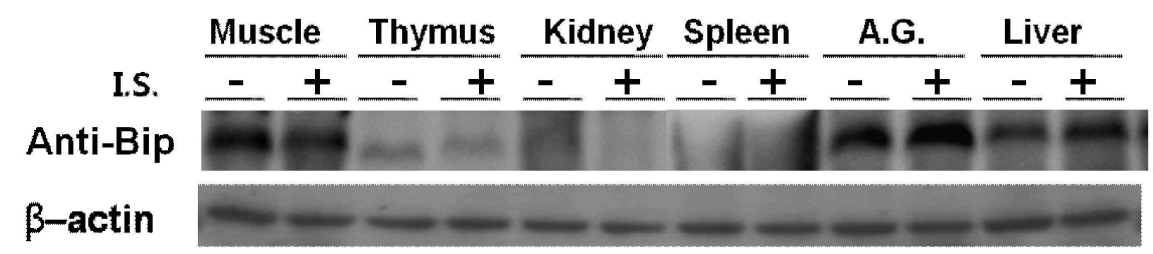

Fig. 1. Effect of the immobilization stress on the unfolded protein response (UPR)-associated gene expression in the each organ. Adult Sprague Dawley rats were housed under controlled conditions on a $12 \mathrm{~h}$ light/12 $\mathrm{h}$ dark cycle and provided with food and water at libitum. Rats were handled daily for 7 days before experiments to minimize the stress of handling. Rat were immobilized by strapping for $6 \mathrm{~h}$ according to Kvetnansky \& Mikulaj methord [4]. Control rats walked freely. Each gene expression was estimated by RT-PCR(A) and tested by Western blotting to estimate those translational level(B). Vertical axis of Fig. 1A indicates relative gene (mRNA) expression. Detailed preparation of each sample was described in the Material \& Method Rabbit anti-Bip antibody and anti-actin antibody were obtained from Santa Cruz Biotechnology (Santa Cruz, CA, USA). The bar graph shows the averages of the quantified data from 3 independent experiments. I.S. (immobilization stress) \& A.G. (adrenal gland). 
(ER degradation-enhancing alpha-mannosidase-like 1), ER lumen에서 잘못 형성된 단백질의 -S-S-를 인식하여 고쳐주는 PDI (protein disulfide isomerase)와 유사한 기능의 ERp29, ERp72 그리고 전자공여단백질인 Ero1 (ER oxidoreductin 1) 을 포함하는 redox chaperones, ER stress signal의 sensor 역 할을 하는 ATF6 (activating transcription factor 6), IRE1 (inositol requiring ER-to-nucleus signal kinase 1), PERK [double-stranded RNA-activated kinase (PKR)-like ER kinase] 그리고 전사수준에서 UPR을 apoptosis 혹은 inflammation을 결정하는 전사인자인 CHOP (CCAAT/enhancer binding protein homologous protein). Control로 ER membrane에 있는 Rpn1 (ribophorin 1)을 사용하였다.

Heart, spleen, thymus, kidney, testis에서는 어떤 유전자도 통계적으로 유의성 있는 발현의 차이가 관찰되지 않았다, 그 러나 adrenal gland, liver, lung, muscle에서는 유의성 있는 유전자의 발현차이가 관찰되었다(Fig. 1A). 전체적인 발현양 상은 adrenal gland, liver, lung에서는 발현이 상승하는 유전 자들이 관찰된 반면에 muscle에서는 전체적으로 발현이 억제 되었다. 가장 심한 유전자발현의 차이를 보인 것은 adrenal gland였다. Adrenal gland에서는 ER lumen의 Bip (약 1.5배) 과 GRp94 (약 3배)는 동시에 상승 발현하였지만 calreticulin은 변화가 없고 calnexin (약 2.5배)은 상승 발현하였다. Redox chaperone중에서는 ERp72 (약 3배)만 높은 발현을 보였다. 그 리고 ER stress sensor중에서는 PERK(약3.5배) 발현이 상승하 였지만 나머지는 큰 변화를 보이지 않았다. 일반적인 스트레스 는 대뇌피질에서 인식하여 시상하부(hypothalamus)로 전달되 며 시상하부는 뇌하수체(pituitary)로 corticotropin-releasing hormone $(\mathrm{CRH})$ 을 방출한다. 이로 인해 혈장으로 분비된 corticotropin이 부신피질(adrenal cortex)의 corticotropin receptors를 자극하여 혈액내로 cortisol을 분비한다. 시상하부의 cortisol receptor는 $\mathrm{CRH}$ 생성을 감소시켜 항상성을 유지한다. 이와 같이 일반적인 스트레스를 가장 잘 전달하고 조절하는 기관이 adrenal gland이다. 이런 관점에서 부동스트레스 역시 타 종류의 스트레스와 동일하게 작용 및 응답하기 때문에 가 장 강하게 ER stress와 관련 유전자의 변화를 유도하는 것으로 추정할 수 있다. Liver의 CHOP의 상승발현(약 2배)이 주목된 다, liver에서의 경우는 부동스트레스가 apoptosis 혹은 inflammation을 선택하는 전사인자 $\mathrm{CHOP}$ 의 발현만이 높아진 것은 이들의 선택에 밀접한관계가 있을 것으로 추정된다. Lung에서는 IRE1의 발현이 2배 이상 상승하였으며 나머지는 특이적으로 주목할 만한 발현변화는 없었다. Muscle의 경우는 전체적으로 발현 감소하였다. Control에 비교하여 $1 / 2$ 정도까 지 발현이 감소된 것은 ERp29, IRE1이다, 그중에서 IRE1이 가장 강하게 발현이 억제되었다. 근육에서 이처럼 모든 유전 자발현이 감소되는 것은 동물에게 부동스트레스로 말미암아 서 새로운 단백질합성이 일어나지 않기 때문에 ER lumen에서
단백질생합성에 관련하는 모든 유전자들의 활성이 떨어졌기 때문으로 추정된다. 부동스트레스는 ER stress 관련유전자의 변화는 각각 차이가 많지만, Rpn1의 발현이 약 3.5 배 상승한 것으로 보아서 ER lumen에 UPR과 관련 있는 변화가 심하게 일어나 비정상적인 단백질축적에 의해서 $\mathrm{ER}$ 자체가 많이 커 진 것으로 추측할 수 있다. 위의 결과는 유전자 전사수준에서 조절되는 것을 확인인한 결과이다. Fig. $1 \mathrm{~B}$ 에서는 이들의 변화 가 단백질 번역수준에서도 적용되는지를 알기위하여 ER lumen의 대표적인 chaperone인 $\mathrm{Bip}$ 의 변화를 관찰하였다. 전사 수준의 양상과 동일하게 muscle에서는 부동스트레스에 의해 서 발현이 억제되고 adrenal gland, liver에서는 발현이 상승하 였다. 나머지는 발현의 변동이 관찰되지 않았다.

결론적으로 부동스트레스는 세포의 ER stress와 관련된 유 전자발현의 변화를 유도한다. 즉 Heart, spleen, thymus, kidney, testis에서는 유전자발현 변화가 없었지만 adrenal gland, liver, lung에서는 유의할만한 상승변화가 있었다. 그러나 muscle에서는 다른 것들과 대조적으로 발현이 감소되었다. 이 결과는 부동스트레스도 다른 종류의 cell stress와 같이 세포수 준에서 UPR을 조절할 수 있다는 최초의 보고이다.

\section{감사의 글}

This work was supported by the National Research Foundation of Korea (NRF) grant funded by the Ministry of Education, Science and Technology of Korea (MEST) (No.2012-0001830).

\section{References}

1. Das, A., Kapoor, K., Sayeepriyadarshini, A. T., Dikshit, M., Palit, G. and Nath, C. 2000. Immobilization stress-induced changes in brain acetylcholinesterase activity and cognitive function in mice. Pharmacol. Res. 42, 213-217.

2. Hetz, C. 2012. The unfolded protein response: controlling cell fate decisions under ER stress and beyond. Nat. Rev. Mol. Cell Biol. 13. 89-102.

3. Kim, P. S. and Arvan, P. 1998. Endocrinopathies in the family of endoplasmic reticulum (ER) storage diseases: disorders of protein trafficking and the role of ER molecular chaperones. Endocr. Rev. 19. 173-202.

4. Kvetnansky, R. and Mikulaj, L. 1970. Adrenal and urinary catacholamines in rats during adaptation to repeated immobilization stress. Endocrinology 87, 738-743.

5. Larco, D. O., Cruthirds, D. F., Weiser, M. J., Handa, R. J. and $\mathrm{Wu}, \mathrm{T}$. J. 2012. The effect of chronic immobilization stress on leptin signaling in the ovariectomized (OVX) rat. Endocrine [Epub ahead of print].

6. Liu, J., Wang, X., Shigenaga, M. K., Yeo, H. C., Mori, A. and Ames, B. N. 1996. Immobilization stress causes oxidative damage to lipid, protein, and DNA in the brain of rats. 
FASEB J. 10, 1532-1538.

7. Paek, N. H., Kwak, S. S., Lee, D. S. and Lee, Y. H. 2006. Characterization of peroxiredoxins in the gray matter in the spinal cord after acute immobilization stress. J. Korean Soc. Traumatol. 19. 105-112.

8. Parmar, V. M. and Schröder, M. 2012. Sensing endoplasmic reticulum stress. Adv. Exp. Med Biol. 738. 153-168.

9. Saijo, Y. 2010. ER quality control of immune receptors and regulators in plants. Cell Microbiol. 12. 716-724.

10. Shore, G. C., Papa, F. R. and Oakes, S. A. 2011. Signaling cell death from the endoplasmic reticulum stress response. Curr. Opin. Cell Biol. 23. 143-149.

11. Walter, P. and Ron, D. 2011. The unfolded protein response: from stress pathway to homeostatic regulation. Science 334. 1081-1086.

\section{초록 : 부동스트레스에 의한 소포체스트레스반응 조절}

권기상 ${ }^{1}$ · 권영숙 ${ }^{2}$ · 김승환 ${ }^{3}$ · 김동운 ${ }^{1}$ - 권오유 ${ }^{1}$ *

('충남의대 해부학교실, ${ }^{2}$ 중부대학교 간호학과, ${ }^{3}$ 충남대병원 응급의학과)

많은 종류의 세포스트레스는 unfolded protein response (UPR)관련인자의 유전자발현을 조절한다. 본연구결 과 부동스트레스(immobilization stress)는 세포의 소포체스트레스(ER stress)와 관련된 유전자발현의 변화를 유도 한다; Heart, spleen, thymus, kidney, testis에서는 유전자발현 변화가 없었지만 adrenal gland, liver, lung에서는 유의할만한 상승변화가 있었다. 그러나 muscle에서는 다른 것들과 대조적으로 발현이 감소되었다. 이 결과는 부 동스트레스도 다른 종류의 세포스트레스와 같이 세포수준에서 UPR을 조절할 수 있다는 최초의 보고이다. 